Self-Management Recommendations for Sickle Cell Disease: A Content

\title{
Analysis of Websites
}

Authors

DRUYE, A. Andrews ${ }^{1}, \mathrm{RN}, \mathrm{MPH}, \mathrm{PhD}$

School of Nursing and Midwifery, University of Cape Coast, Ghana

NELSON, Katherine ${ }^{2}$, RN, MA, PhD

Graduate School of Nursing, Midwifery \& Health, Victoria, University of

Wellington

ROBINSON, Brian $^{3}, \mathrm{MSc}, \mathrm{PhD}$

Graduate School of Nursing, Midwifery \& Health, Victoria, University of Wellington

ORCID ID: https://orcid.org/0000-0002-1614-6579

\section{Correspondence:}

Dr. Andrews Adjei Druye

School of Nursing and Midwifery,

College of Health and Allied Sciences,

University of Cape Coast,

Cape Coast, Ghana.

E-mail: andrews.druye@ucc.edu.gh

This article has been accepted for publication and undergone full peer review but has not been through the copyediting, typesetting, pagination and proofreading process which may lead to differences between this version and the Version of Record. Please cite this article as doi: $10.1111 /$ nhs. 12741 
Telephone: (+233) 503187902

\section{Authors Contribution:}

Study design: AAD, KN, BR

Data collection: AAD

Data analysis: AAD, KN, BR

Manuscript writing: AAD, KN, BR

\section{Acknowledgment}

The authors acknowledge the Victoria University of Wellington for logistic support. We also acknowledge the efforts people who have created the sickle cell support websites that were included in this study.

\section{Conflict of Interest}

There is no conflict of interest has been declared by the authors

\section{Authorship statement}

All three authors have approved the final version of this manuscript and have all agreed to be accountable for the subsequent stages of this work.

Word count: 4,780 


\begin{abstract}
This paper reports on the findings of a study designed to establish website-based selfmanagement recommendations for sickle cell disease. Google and Yahoo search engines were used to search the World-Wide-Web. Purposive sampling was utilized to select 28 websites that met the inclusion criteria. Data were manually collected from health education materials and subjected to qualitative content analysis. Self-management was conceptualized as actions involving preventive health, self-monitoring, self-diagnosing, and self-treatment. The results show that the websites recommend more self-management actions for preventive health and self-treatment than for self-monitoring and self-diagnosis. Frequent oral fluid intake, limitation of overactivity, eating a healthy diet, avoiding extreme temperatures, and infections were the commonest preventive health recommendations. Daily pain monitoring and general bodily inspections were the most frequent selfmonitoring recommendations. Commonly cited self-diagnostic indicators were fever, persistent pain, enlarged spleen, and leg ulcers. The use of analgesics and nonpharmacological measures were regularly cited for self-treatment. Most recommendations were assessed as clinically safe as they align with standards for sickle cell management. Nurses and other professionals should teach patients how to assess the credibility of websites.
\end{abstract}


Keywords: Content Analysis, Chronic Disease, Sickle Cell Disease, Self-Management, Websites, Recommendations 


\section{INTRODUCTION}

Sickle Cell Disease (SCD) is chronic, and providing adequate health services to treat affected people remains challenging to nations with low financial resources in low and middle-income countries (McGann, Hernandez, \& Ware, 2017; Odame, 2015; UN, 2009). Despite the global prevalence of SCD (Piel et al., 2013), evidence that complications can be managed and reduced has mainly focused on clinical care (Chakravorty \& Williams, 2015; National Heart Lung \& Blood Institute, 2014). There are limited published standards for self-management unlike other chronic conditions such as diabetes, cancer, and HIV (Ministry of Health NZ, 2014; Self Management Resource Centre, 2019). Being a chronic disease, SCD patients manage approximately $90 \%$ of the daily care by themselves (McGowan, 2011; Smith \& Scherer, 2010). Therefore, in addition to clinical management, patients require knowledge, skills, and support for self-management.

In recent decades, self-management has been accepted as the best approach for managing chronic conditions such as SCD (Anekwe \& Rahkovsky, 2018). Selfmanagement concerns a situation when patients actively participate in the management of their conditions. Adams, Greiner, and Corrigan (2004) define self-management as "relating to the task an individual must undertake to live well with one or more chronic conditions. These tasks include gaining confidence to deal with medical management, role management, and emotional management" (p. 57). The effectiveness of self-management programs in improving the quality of life of people living with chronic conditions and benefits to health systems is well documented (Ahn et al., 2013; Brady et al., 2011; Lorig, Ritter, Ory, \& Whitelaw, 2013; Ory et al., 2013). For patients to engage effectively with 
self-management, health professionals should provide self-management support in the form of education and skills training, self-monitoring devices, and show them community networks that can offer additional support (Ministry of Health NZ, 2014; Ryan \& Sawin, 2009).

Despite the recognition of the importance of self-management to SCD (Chakravorty \& Williams, 2015; Gill, Lavin, \& Sim, 2010) there are limited publications on the application of evidence-based self-management programs for SCD. A recently published self-care kit for SCD by the Centre for Disease Control (CDC) mainly focuses on how patients should organize their medical information and interact with health professionals (CDC, n.d). The kit is suitable for the literate population with access to comprehensive SCD care but will have limited utility for patients in many developing countries where there is limited comprehensive SCD care. A different model of SCD self-management is required in health systems with limited provision of comprehensive care.

Existing recommendations for SCD management in textbooks and protocols present limited information on patients' responsibilities that reflect self-management, rather they mostly focus on clinical prevention such as immunization and screening for complications, and advice that health professionals should provide to patients for healthy living (Chakravorty \& Williams, 2015; Gill et al., 2010; National Heart Lung \& Blood Institute, 2014). Often, patients' responsibilities for self-management relate to acute pain with limited recommendations for managing other complications such as chronic pain, fever, leg ulcers, and splenic enlargement. 
Furthermore, research on SCD related self-management in the literature has mainly focused on testing the feasibility of pain self-monitoring tools and home-based pain treatment (Jacob, Duran, Stinson, Lewis, \& Zeltzer, 2013; McClellan et al., 2009), description of lived experiences and coping (Forrester, Barton-Gooden, Pitter, \& Lindo, 2015; Jenerette, Brewer, \& Leak, 2011), and testing of theories of self-management and determinants (Jenerette \& Murdaugh, 2008; Matthie, Jenerette, \& McMillan, 2015). These studies have a limited focus on self-management guidelines or standards that could be used by patients. In the absence of such published standards, patients are likely to seek information from various sources including the Internet.

Worldwide, most people affected by chronic diseases such as SCD use an array of self-management strategies (Grady \& Gough, 2014). For many people, their actions will be informed by information received from the internet as the World-Wide-Web (WWW) offers a rapidly growing source of free and public health information (Wong et al., 2014), and access to the internet is increasing in many countries including developing countries (International Communication Union, 2020). To date, the only published research that has been reported about the information SCD-focused websites provide is a paper by Breakey et al. (2017) that examined the suitability of website information for SCD. However, Breakey et al.'s study focused on readability characteristics rather than the messages that advise people on what to do for self-management. This paper reports on the findings of a study designed to address the question "What information do the websites of SCD support organizations recommend for SCD self-management in terms of keeping well, reducing complications and managing complications". We wished to describe and relate the 
information SCD support websites recommend people could use to self-manage (the medical dimension) their own or their child's SCD in relation to guidelines for SCD management. Understanding what self-management information is readily available on the WWW is important for health professionals to judge the safety of information provided for patients' use.

\section{METHODS}

\subsection{Design}

A structured website study was undertaken. The data collection and analysis were informed by two publications on website content analysis (McMillan, 2000) and qualitative content analysis (Hsieh \& Shannon, 2005)(Table 1).

$<$ Insert Table 1 here>

\subsection{Searching and Sampling the WWW}

A keyword search was conducted in the WWW using the commonly used search engines Google and Yahoo (Search Engine Watch, 2016). The keywords for SCD were sickle cell, sickle cell anemia, and sickle cell disease, consistent with the NIH classification of SCD (National Heart Lung \& Blood Institute, 2014). These terms were combined with terms that reflect SCD support organizations that were selected after a cursory look at the websites including association, clubs, organization, society, and foundation (Figure 1). Following the example of similar research (Breakey et al., 2017; Siddhanamatha et al., 2017) the first 20 
websites for each search were manually screened and those that met the inclusion criteria were selected.

Inclusion criteria were that the website provided clinical or psychosocial support, information and education to patients, families, or guardians. The information provided had to refer to what people could or should do for themselves or their children or family members with SCD. Recommendations concerning when people should consult with health professionals were included as self-management also concerns interaction with health professionals (Grady \& Gough, 2014). Exclusion criteria were websites that focused only on charity, fundraising, or clinical management of SCD by health professionals, and the webpage was not available. Duplicated websites from the same search engines were omitted. In selecting the websites, we focused on official websites as the sampling unit. Facebook, directories pages, news items, and posts were excluded. The initial search was conducted between May to June 2014 and repeated between February 2018 and October 2019 (Table 2). No ethics review was required as only publicly available websites were accessed.

\section{< Insert Figure 1 here:>}

\subsection{Data collection}

At each of the selected websites, data were collected from health education materials including webpages, audio-visuals, books, posters, leaflets, policy documents, and PowerPoint presentations. The materials provided had to be located at the websites' homepage or link to materials on the same website and had to be free of charge. Materials from 
national and international health institutions such as CDC, NIH, and WHO were excluded in the data extractions as these documents served as the criteria for judging the safety of the websites' recommendations.

Once the materials were located, the content was extracted from messages that provided information to patients or guardians (including parents and teachers) on keeping well, reducing complications, and managing complications. The messages retrieved had to ask patients or guardians to engage in some performance, hence clues such as "you", “patients", "parents", "teachers", “care-givers" were used in selecting the messages. The extractions included sections, pages, sentences, paragraphs, and words. Text data were copied into Microsoft word format, and videos were transcribed verbatim in word format to generate transcripts.

\subsection{Data analysis}

The analysis followed the recommendations for conducting deductive and summative content analysis proposed by Hsieh and Shannon (2005) (Table 1). Data extraction and coding was conducted by AAD and confirmed by $\mathrm{KN}$ and BR. The initial coding concepts were derived from a conceptual framework developed from a review of previous research, theories, and models of chronic disease and SCD self-management (Druye 2017). The categories (preventive health and maintenance behaviors, self-monitoring, self-diagnosis, and self-treatment) were formed from the components of the conceptual framework and served as lenses for data collection and analysis. During coding, all text that directed patients or guardians to engage in some responsibility was highlighted and coded to 
correspond to the categories for the study using NVIVO. Text that did not fit in the categories were filed under "other". Further analysis of the categories was conducted to derive subcategories using a codebook that captured the categories, subcategories, and quotations reflecting the subcategory. Thereafter, the codebook was updated and the subcategories were applied back to the transcripts to test for fitness. This resulted in collapsing, removing, or adding some subcategories. The number of websites that made references to each of the categories and subcategories was counted to determine the frequency of quotes (Tables 4A\&B). The results were described through themes that emerged from the subcategories and exemplary quotes were used to support the descriptions.

\section{RESULTS}

\subsection{Sources of websites and materials analyzed}

The majority of the 28 websites analyzed were from North America (USA [18], Canada [3], and Jamaica [1]), four were from Europe (UK [3] and Norway [1]) and one website each was from Australia and Africa (Uganda). In presenting the findings, sources of websites are referred to by abbreviations such as US1, UG (Table 2). The types of the 57 materials located that covered self-management in descending order were, web pages $(n=23,40.4 \%)$, books $(\mathrm{n}=15,26.3 \%)$, posters and leaflets $(\mathrm{n}=10,17.5 \%)$, audio-visual comprised $(\mathrm{n}=7$ 12.2\%), and PowerPoint slides $(\mathrm{n}=2,3.5 \%)$ (Table 3). The primary targets for most materials were patients and parents. Secondary targets were teachers, employers, and health professionals. 


\subsection{Self-management recommendations}

The websites provided more information on preventive health and self-treatment than the other categories (Table 4A).

\subsubsection{Preventive health}

Eight areas of preventive health recommendations were identified in 21 websites (Table 4A). Hydration and nutrition were the most frequent recommendations.

\section{Regular oral fluids intake (Hydration)}

The websites promoted hydration as an efficacious health promotion measure for SCD patients. The websites advised SCD patients to frequently drink oral fluids to prevent dehydration and crisis. Water was the most recommended fluid to drink and other fluids were "soft drinks", "fruit juices", and soup. The Ugandan website also recommended that patients should take oral rehydration salt daily. The websites specified the daily requirements for water with variations in units of measurements. Some websites expressed specific requirements in the number of glasses per day (8-10 for adults; 4 for children), and other websites related the number of glasses to an individual's body weight. Patients were advised to increase fluid intake during exposure to extended sunlight, cold weather, swimming, and during air travel.

\section{Eating a healthy diet (Nutrition)}


Seventeen websites recommended patients consume healthy diets with balanced selections of food using the food pyramid as a guide. A healthy diet was expressed as a "nutritious diet", "well-balanced diet", or a "good diet". Frequently recommended nutrients were vitamins, minerals salts, and proteins and that food items should be selected from legumes, vegetables, grains, fruit, nuts, and seeds. Patients were advised to eat three square meals with snacks in between to meet their extra energy requirements but cautioned against eating "sweets" to reduce obesity. One website (UG) recommended patients "take diluted boiled avocado leaves or fresh beetroot once in 3 months for adults and 2 months for babies helps in boosting hemoglobin levels".

\section{Taking supportive medications}

Twelve websites recommended that in addition to vaccinations, patients take certain medicines daily for health promotion and protection. Medicines for health promotion included folic acid, vitamin supplements, and herbal medicines. Folic acid was the most recommended medicine for health promotion and was mainly recommended to promote erythropoiesis. The use of folic acid supplements, rather than dietary sources, were mostly promoted, but there were variations in the dosages. US2 recommended $1 \mathrm{mg} / \mathrm{day}$ irrespective of age and body size, NW recommended 400 micrograms (mg) for adults, $600 \mathrm{mg}$ for pregnant women, and that supplements should be started from initial diagnosis of SCD regardless of age and genotype. Two websites (CA1, NW) also recommended other supplements including zinc, L-arginine, blackstrap molasses, Diascovite, and vitamin C to boost immunity and promote growth. 
Penicillin prophylaxis was the most recommended preventive medication. Different websites recommended different ages for commencement and completion of oral penicillin. CA1 indicated that penicillin should commence at two months of age whereas the US2 website recommended penicillin for all newly diagnosed SCD patients. Three websites described ages (range 4-6 years) at which the prophylaxes must be completed. CA1 indicated that penicillin must be completed after the commencement of vaccination whereas other websites such as the UK 2 and UK 3 websites indicated that parents should discuss continued penicillin use with their healthcare workers after six years of age. A twice-daily dose of $125 \mathrm{mg}$ up to age 6 years and 250mg beyond six months was recommended.

\section{Medicines food, and beverages to avoid}

Eleven websites cautioned patients not to take iron supplements (iron medicines, blood tonics, \& artificial iron) and recreational drugs including cocaine, cigarettes, and alcohol. The websites also cautioned against the use of analgesics containing aspirin and nasal decongestants such as pseudoephedrine as these can cause Rye's syndrome and painful crisis respectively. The food and beverages patients were advised to avoid included high sodium foods, tea, coffee, citrus juices, and diet sodas. These foods and beverages were described as having diuretic properties that can cause dehydration and sickling.

\section{Hygiene and Infection Prevention}

Fifteen of the websites advised that SCD patients should ensure proper hygienic measures to reduce infections, especially, cold or flu during hospitalization, home, and public places. During hospitalization, patients should wear face mask sprayed with antibacterial or anti- 
viral oils (e.g., Manuka oil \& eucalyptus oil) when the people around them have a cold or flu. After hospitalization, the advice included that patients should disinfect all personal items, fomites, and surfaces with alcohol, ensure good hand and food hygiene, avoid of reservoirs of infection, and treat infections promptly. The websites also advised patients to stay away from public places during cold or flu seasons or wear the sprayed masks. Some websites provided advice on preventing infections such as sexually transmitted infections, AIDS, malaria, and pneumonia.

\section{Activities and Oxygen Issues}

Sixteen websites provided advice concerning overactivity, and measures to mitigate its effects. Although the websites encouraged SCD patients to engage in moderate physical activities such as play and sports, the websites warned patients that overactivity could result in a painful crisis. Recommended measures to reduce the effect of overactivity include drinking extra fluids, patients set their own pace, having flexible daily schedules, and access to transportation and resting places (especially for school children). It was also recommended to patients to form a habit of learning and practicing resting and relaxation techniques:

Try relaxing lie down, close your eyes, tense all the muscles in your body (not where you have pain) starting with your head, screw your face up, and tense all your body your arms and hands, your legs down to your toes. Hold your body like this for a few seconds and then relax.

Practice this when you feel stressed. (US6) 
Also, many websites cautioned patients to avoid areas and activities that result in low oxygen tension including traveling in unpressured aircraft, sporting activities, mountain climbing, and scuba diving. The websites advised patients to avoid these activities or use supplemental oxygen during air travel, and drink more fluids.

\section{Avoiding extremes of temperature}

Sixteen websites advised patients to avoid too hot or too cold temperatures; the majority concerned cold temperatures. Potential causes of cold temperatures described were exposure to cold objects, swimming in non-heated pools, cold baths, doing laundry, taking cold drinks, getting caught in rain, and exposure to cold weather. Recommended strategies to cope with the effect of cold temperature included wearing warm clothes, controlling internal environmental temperature, using warm water baths, and getting oneself warm and dry after being caught in the rain.

\subsection{Self-monitoring}

Six areas of self-monitoring were recommended from 10 of the websites reviewed (Table 4). These websites advised patients to consistently monitor triggers of pain and other indicators to facilitate early detection of problems.

\section{Pain monitoring}

Nine websites advised patients to identify triggers of their SCD pain so that they could then avoid such triggers. Most of these websites advised patients to recall what they were doing 24 hours before the pain occurred and record these activities in a diary. The US3 website 
presented three mobile apps (the VOICE, POMS, and Sickle-O-Scope) that help SCD

patients track their pain and other symptoms and communicate these with health

professionals. The functions of one of these apps were described as follows:

The VOICE Crisis Alert mobile a sickle cell disease crisis tracking and communicating app with useful features that are easy to use. With a tap, users can record their websites of pain and the level of severity in addition to the date, time, and attempted intervention. (US3)

Other websites recommended the use of pain rating scales for patients to monitor their pain and the development of an individualized pain monitoring plan in collaboration with their health care providers.

\section{General inspection, splenic palpation, fever, stroke and growth monitoring}

Four websites indicated the need for parents and caregivers to inspect the SCD patients' inner eyelids, tongue, palms, and lips daily for paleness, jaundice, and general skin condition. Parents were advised they should also palpate the splenic area every morning, and check their children's temperature twice daily when the child is sick. The US1 website advised teachers to develop an individualized fever monitoring plan for a student with SCD that lays out instructions for what should be done when the child experiences fever at school. Three websites also advised parents and schoolteachers to monitor the growth and development of SCD children as these children are prone to stunted growth. Regarding stroke monitoring, two websites advised teachers to watch for signs of silent stroke among 
school children such as changes in school performance, inability to maintain attention, and delays in vocabulary development.

\subsection{Self-diagnosis}

Nine areas of physical and physiological indicators that patients should consider as an emergency and take immediate actions were located in 12 websites. The commonest of these recommendations were fever and infections, worsening pain, and leg ulcers (Table 4B).

\section{Fever and other infections}

The websites referred to the level of fever that requires medical attention in quantitative and qualitative terms. Quantitative terms were cited in Centigrade $\left(37.2^{\circ}, 38^{\circ}, 38.4^{\circ}, 38.5^{\circ}\right)$ and Fahrenheit $\left(101^{\circ}, 101.3^{\circ}\right)$ and the qualitative terms included "fever" and "high fever": In the event of fever, most websites advised patients to seek "prompt" medical help and avoid the use of analgesics; However, the UG recommended the use of paracetamol before seeking medical assistance.

\section{Worsening pain, leg ulcers, priapism, and splenic issues}

The websites advised patients to seek medical help if their pain persists or worsens after trying home remedies, when they observe signs of leg ulcers (a cut around the ankles, a cut or wound that doesn't heal, a patch of dry itchy skin, and a small dark spot that is surrounded by painful swelling), or when males patients experience priapism. On the spleen, parents were advised to report a pinball-like or football-like swelling in the splenic 
area or when children developed abdominal pains with systemic signs such as anemia, jaundice, and dark urine. Regarding stroke, parents were advised to report weakness or change in motor function such as seizures, speech problems, paralysis, and changes in memory and learning capacity.

\subsubsection{Self-treatment}

Fifteen websites recommended 20 different self-treatment actions when illness or problems are recognized. The actions concerned strategies for managing painful crises and other complications (Table 4B).

\section{Pain self-treatment}

Painful crisis management strategies, involving pharmacological and non-pharmacological measures were recommended by nine websites. Recommended measures included taking analgesics such as acetaminophen/paracetamol, Tylenol, NSAIDs, ibuprofen/brufen, and diclofenac. Two websites (US2, UK1) recommended specific dosages of analgesics for home pain management. The UK1 recommended the following:

The gentlest analgesic to try is paracetamol, given three times a day (62.5 mg under 12 months, $125 \mathrm{mg} 1$-4 years, $250 \mathrm{mg} 4-10$ years, 500 mg 10-14 years, and 1 gm 15 years upwards). The next gentlest is codeine phosphate, given four times a day, at 1-2 mg for every kilogram of body weight of the sufferer. A stronger analgesic is a nonsteroidal anti-inflammatory agent, such as Diclofenac, which is given 
three times a day, at a dose of $1 \mathrm{mg}$ for every kilogram of body weight of the sufferer.

Other recommended measures for pain relief include taking extra fluids (at least twice the usual daily intake), applying heat and massaging the painful part, ensuring adequate rest, and using varieties of pain distractive methods. One website described how deep breathing could promote relaxation among children:

Have your child take a few deep breaths and let them out to the slow count of $1 \ldots 2 \ldots 3 \ldots$ Or have your child pretend to be a bicycle tire that the air is going out of slowly. Try one of these ways to keep the deep breathing going for a while. Tell her to pretend that she can breathe underwater if she breathes in this special way. Or she can pretend to be an astronaut in a spacesuit who has to breathe deeply and evenly. (US1)

\section{Fever self-treatment}

Four websites recommended that parents send their SCD children to the hospital for fever management. Three of these websites recommended that antipyretics should be given only after consultation with health professionals. However, UG recommended giving analgesics without having consulted health professionals. Generally, the websites advised that people should avoid giving analgesics before checking their child's temperatures.

\section{Leg ulcer, aseptic necrosis, and priapism}


Recommendations for managing leg ulcers included paying immediate attention to cuts, scrapes, and bites by washing with antiseptics, wearing "compression garments" and "proper socks and shoes", strict bed rest with elevation of the affected leg to reduce swelling, and "keeping the area clean." People with aseptic necrosis of head-of-femur were advised to undertake low impact activities such as sitting down and lifting their legs, avoid lifting heavy objects, and avoid exercises that involve jumping and jogging. Regarding dactylitis, it was recommended that the affected hand should be placed in a bandage, and patients should be given more fluids, analgesics, and rested. Parents should avoid rubbing or pressing the affected part as these will cause more pain. Patients experiencing episodes of priapism were advised to drink lots of water and empty their bladder frequently.

Most of the recommendations were assessed as being clinically safe as they coincide with guidelines for SCD management from national and international health agencies such as (CDC, n.d; National Heart Lung \& Blood Institute, 2014; WHO, 2005). There were four potentially unsafe and clinically problematic recommendations present on the websites; no one website was particularly problematic. These include recommendations where there is no evidence in the literature or guidelines for the action or therapy in the management of SCD. Unsafe recommendations concerned the advice to regularly take Oral Rehydration Salt (normally taken for the management of acute diarrhea (WHO, 2006)), taking biochemical products such as L-arginine, blackstrap molasses or vitamin C, taking herbal medicines, and bandaging painful limbs. 


\section{DISCUSSION}

Collectively the websites provide extensive self-management recommendations for SCD care. The findings indicate that most recommendations concerned actions related to preventive health and pain self-treatment. Limited recommendations were noted for selfmonitoring and self-diagnosis.

The finding that most recommendations concerned preventive health, corroborates research in the US which elicited recommendations for self-management among adults and middle-aged patients with SCD (Jenerette et al., 2011). However, contrary to the current study, where some recommendations were recorded for self-monitoring, self-diagnosis, and self-treatment, Jenerette et al.'s findings almost entirely concerned preventive health. The difference in findings can be attributed to the different research approaches. Jenerette et al. interviewed adults who had lived beyond the median age of people who die from SCD to understand what contributed to their longevity. The interview data were then analyzed for "responses to the...statement: tell me what you think adults with sickle cell disease need to do to best take care of themselves". Our study concerns the recommendations provided in the websites for all age groups.

The findings of our study show that some topic areas were almost universally recommended by the websites. These included regular intake of oral fluids, eating a healthy diet, infection prevention through vaccination and penicillin prophylaxis, folic acid supplementation, avoiding overactivity and extremes of temperature, and the use of 
analgesics for pain management at home. These findings may reflect the importance of these actions for SCD care and provide lessons for consideration in services provision.

The study revealed that the underlying health conditions for most recommendations were pain, fever, and anemia, with pain being the commonest. These findings mirror the common problems of SCD reported in the literature and are consistent with the wider research focus for SCD self-management (Ferreira, Cordeiro, Cajuhy, \& Souza da Silva, 2013; Jacob et al., 2013; Jenerette et al., 2011; Matthie et al., 2015; Tanabe et al., 2010). Furthermore, some websites provided advice on how patients could subjectively and objectively monitor their pain and other symptoms including the use of instruments such as thermometer, pain scales, diaries, and mobile apps. Clinician awareness of these findings may assist them to develop tools that are feasible and acceptable by patients and parents to support self-management.

It is heartening to find that apart from pain and fever, some websites provided insights into self-management for complications which are rarely discussed in the medical literature including leg ulcer, priapism, avascular necrosis of the head of femur, dactylitis, and stroke. Although limited recommendations were reported for these topics, the information provided gives useful insights for service provision and future research.

Although several self-management topics were described by the websites, no single website had recommendations for all the topics. Furthermore, even where websites described the same topic, there were variations in how the websites advised that the action should be applied. For example, the UK and US websites recommended that SCD patients 
with fever should be rushed to the hospital, the Uganda website recommended that patients take antipyretics before going to the hospital. Variations were also noted in the quantity of water recommended and time for commencement and cessation of penicillin prophylaxis. One explanation for these differences in coverage of topics and application of selfmanagement actions in the various websites is that the content may reflect the health systems of the country where the websites are based. Another explanation is the lack of internationally agreed criteria for self-management of SCD. A major issue with the variability is that people with SCD and parents of children with SCD have to look at several websites to gain a comprehensive picture of how to self-manage. Patients and parents could also be confused about what information they should take from the websites for their selfmanagement.

Recommendations for consuming supplements and other biochemical products were made with no reference to discussion or prescriptions with health professionals as such supplements and products could result in adverse drug-drug or drug-food supplements interactions (Patel \& Beckett, 2016).

The study has four main limitations. Some relevant websites might have been excluded from the sample as the study was limited to only English language websites, and the first 20 outputs of each website only were reviewed. Secondly, some relevant texts might have been omitted or over-counted as data were manually collected and counted. Thirdly, as websites typically change regularly, the information located in the websites for this research may have already been changed. Fourthly, the authors of the websites were not included as the websites indicated the names of the organizations as the authors. 


\section{CONCLUSION}

The majority of the website provide recommendations that are consistent with evidencebased recommendations for SCD care. However, there are variations in the number of topic areas described and the recommended process of applying the various measures for selfmanagement. Where possible, nurses and other health professionals should monitor the websites used by patients under their care and direct patients to only those websites that provide safe and feasible recommendations. They could teach patients how to assess the credibility of websites and warn patients about unsafe recommendations on some websites. Internationally, more needs to be done to establish best practice guidelines for the selfmanagement of SCD for patients' use. Researchers should explore the feasibility of using websites to disseminate self-management information for SCD and other chronic conditions in developing countries. 


\section{REFERENCES}

Adams, K., Greiner, A. C., \& Corrigan, J. M. (Eds.). (2004). Report of a summit. The 1st annual crossing the quality chasm summit-A focus on communities. ( ed.). Washington, DC: National Academies Press.

Ahn, S., Basu, R., Smith, M. L., Jiang, L., Lorig, K., Whitelaw, N., \& Ory, M. G. (2013). The impact of chronic disease self-management programs: Healthcare savings through a community-based intervention. BMC Public Health, 13, 1141. doi:10.1186/1471-2458$13-1141$

Anekwe, T. D., \& Rahkovsky, I. (2018). Self-Management: A comprehensive approach to management of chronic conditions. American Journal of Public Health, 108(S6), S430S436.

Brady, T. J., Murphy, L., Beauchesne, D., Bhalakia, A., Chervin, D., Daniels, B., ... O'Colmain, B. (2011). Sorting through the evidence for the arthritis self-management program and the chronic disease self management program: Executive summary of ASMP/CDSMP meta-analyses Retrieved from http://www.cdc.gov/arthritis/docs/ASMP-executivesummary.pdf

Breakey, V. R., Harris, L., Davis, O., Agarwal, A., Ouellette, C., Akinnawo, E., \& Stinson, J. (2017). The quality of information about sickle cell disease on the Internet for youth. Pediatric blood \& cancer, 64(4), n/a-n/a. doi:10.1002/pbc.26309

CDC. (n.d). Living well with sickle cell disease: Self-care toolkit. (CS226674-B). Retrieved from https://www.cdc.gov/ncbddd/sicklecell/healthyliving-living-well.html.

Chakravorty, S., \& Williams, T. N. (2015). Sickle cell disease: A neglected chronic disease of increasing global health importance. Arch Dis Child, 100(1), 48-53. doi:10.1136/archdischild-2013-303773

Ferreira, S. L., Cordeiro, R. C., Cajuhy, F., \& Souza da Silva, L. (2013). Vulnerability in adults with sickle cell disease: Subsidies for nursing care. Ciencia, Cuidado e Saude, 12(4), 711-718 718p. doi:10.4025/cienccuidsaude.v12i4.18723

Forrester, A. B., Barton-Gooden, A., Pitter, C., \& Lindo, J. L. (2015). The lived experiences of adolescents with sickle cell disease in Kingston, Jamaica. Int J Qual Stud Health Wellbeing, 10, 28104. doi:10.3402/qhw.v10.28104

Gill, V., Lavin, J., \& Sim, M. (2010). Managing sickle cell disease. Nursing Made Incredibly Easy, 8(6), 24-33. doi:10.1097/01.NME.0000388522.79370.d2 
Grady, P. A., \& Gough, L. L. (2014). Self-management: a comprehensive approach to management of chronic conditions. American Journal of Public Health, 104(8), e25e31.

Hsieh, H. F., \& Shannon, S. E. (2005). Three approaches to qualitative content analysis. Qualitative Health Research, 15(9), 1277-1288. doi:10.1177/1049732305276687

International Communication Union. (2020). Statistics. Retrieved from https://www.itu.int/en/ITU-D/Statistics/Pages/stat/default.aspx

Jacob, E., Duran, J., Stinson, J., Lewis, M., \& Zeltzer, L. (2013). Remote monitoring of pain and symptoms using wireless technology in children and adolescents with sickle cell disease. Journal of the American Association of Nurse Practitioners, 25(1), 42-54. doi:10.1111/j.1745-7599.2012.00754.x

Jenerette, C. M., Brewer, C., \& Leak, A. N. (2011). Self-care recommendations of middle-aged and older adults with sickle cell disease. Nurs Res Pract, 270594. doi:10.1155/2011/270594

Jenerette, C. M., \& Murdaugh, C. (2008). Testing the theory of self-care management for sickle cell disease. Research in Nursing \& Health, 31(4), 355-369.

Lorig, K., Ritter, P. L., Ory, M. G., \& Whitelaw, N. (2013). Effectiveness of a generic chronic disease self-management program for people with type 2 diabetes: A translation study. Diabetes Educator, 39(5), 655-663. doi:10.1177/0145721713492567

Matthie, N., Jenerette, C., \& McMillan, S. (2015). Role of self-care in sickle cell disease. Pain Management Nursing, 16(3), 257-266.

McClellan, C. B., Schatz, J. C., Puffer, E., Sanchez, C. E., Stancil, M. T., \& Roberts, C. W. (2009). Use of handheld wireless technology for a home-based sickle cell pain management protocol. Journal of Paediatric Psychology, 34(5), 564-573. doi:10.1093/jpepsy/jsn121

McGann, P. T., Hernandez, A. G., \& Ware, R. E. (2017). Sickle cell anemia in sub-Saharan Africa: Advancing the clinical paradigm through partnerships and research. Blood, 129(2), 155-161. doi:10.1182/blood-2016-09-702324

McGowan, P. (2011). Health promotion, chronic disease, self managment strategies for nurses. Retrieved from https://www.youtube.com/watch?v=8-CCf8KUZtY

McMillan, S. J. (2000). The microscope and the moving target: The challenge of applying content analysis to the World Wide web. Journalism and Mass Communication Quarterly, 77(1), 80-98. doi:10.1177/107769900007700107 
Ministry of Health NZ. (2014). Self-management support for people with long-term conditions. Wellington, New Zealand: Author.

National Heart Lung \& Blood Institute. (2014). Evidenced-based management of sickle cell disease; Expert panel report. Retrieved from https://www.nhlbi.nih.gov/sites/www.nhlbi.nih.gov/files/sickle-cell-diseasereport.pdf.

Odame, I. (2015). Hydroxyurea therapy for sickle cell disease in low-income countries. In S. MacLeod, S. Hill, G. Koren, \& A. Rane (Eds.), Optimizing Treatment for Children in the Developing World (pp. 311-318). Cham: Springer International Publishing.

Ory, M. G., Ahn, S., Jiang, L., Lorig, K., Ritter, P., Laurent, D. D., . . Smith, M. L. (2013). National study of chronic disease self-management: six-month outcome findings. Journal of Aging and Health, 25(7), 1258-1274.

Patel, R. I., \& Beckett, R. D. (2016). Evaluation of resources for analyzing drug interactions. Journal of the Medical Library Association: JMLA, 104(4), 290.

Piel, F. B., Patil, A. P., Howes, R. E., Nyangiri, O. A., Gething, P. W., Dewi, M., . . Hay, S. I. (2013). Global epidemiology of sickle haemoglobin in neonates: A contemporary geostatistical model-based map and population estimates. Lancet, 381(9861), $142-$ 151. doi:Doi 10.1016/S0140-6736(12)61229-X

Ryan, P., \& Sawin, K. J. (2009). The individual and family self-management theory: Background and perspectives on context, process, and outcomes. Nursing Outlook, 57(4), 217225. e216.

Search Engine Watch. (2016). What are the top 10 most popular search engines? Retrieved from https://www.searchenginewatch.com/2016/08/08/what-are-the-top-10-mostpopular-search-engines/

Self Management Resource Centre. (2019). Chronic disease self managment programme. Retrieved from https://www.selfmanagementresource.com/programs/

Siddhanamatha, H. R., Heung, E., de los Angeles Lopez-Olivo, M., Abdel-Wahab, N., OjedaPrias, A., Willcockson, I., . . Suarez-Almazor, M. E. (2017). Quality assessment of websites providing educational content for patients with rheumatoid arthritis. Paper presented at the Seminars in Arthritis and Rheumatism.

Smith, W. R., \& Scherer, M. (2010). Sickle-cell pain:Advances in epidemiology and etiology. ASH Education Program Book, 2010(1), 409-415. 
Tanabe, P., Porter, J., Creary, M., Kirkwood, E., Miller, S., Ahmed-Williams, E., \& Hassell, K. (2010). A qualitative analysis of best self-management practices: sickle cell disease. $J$ Natl Med Assoc, 102(11), 1033-1041.

UN. (2009). Recognition of sickle-cell anaemia as a public health problem: A/RES/63/237. Resolution adopted at the general assembly.Sixty-third session, 1-2. Retrieved from https://www.google.co.nz/search?espv=2\&q=Recognition+of+sicklecell+anaemia+as+a+public+health+problem+UN\&oq=Recognition+of+sicklecell+anaemia+as+a+public+health+problem+UN\&gs I=serp.3...21138.26475.0.28160.8 1.13.0.0.0.0.409.864.2-2j0j1.3.0...0...1c.1.64.serp..80.0.0.75m3NazByRw

WHO. (2005). Sickle-cell anaemia: Report by the secretariat (EB 117/34). Retrieved from http://apps.who.int/gb/archive/pdf files/WHA59/A59 9-en.pdf

WHO. (2006). Oral rehydration salt: Production of new ORS. Retrieved from http://www.who.int/maternal child adolescent/documents/fch cah 06 1/en/ 
Figure 1: Procedure for searching the websites

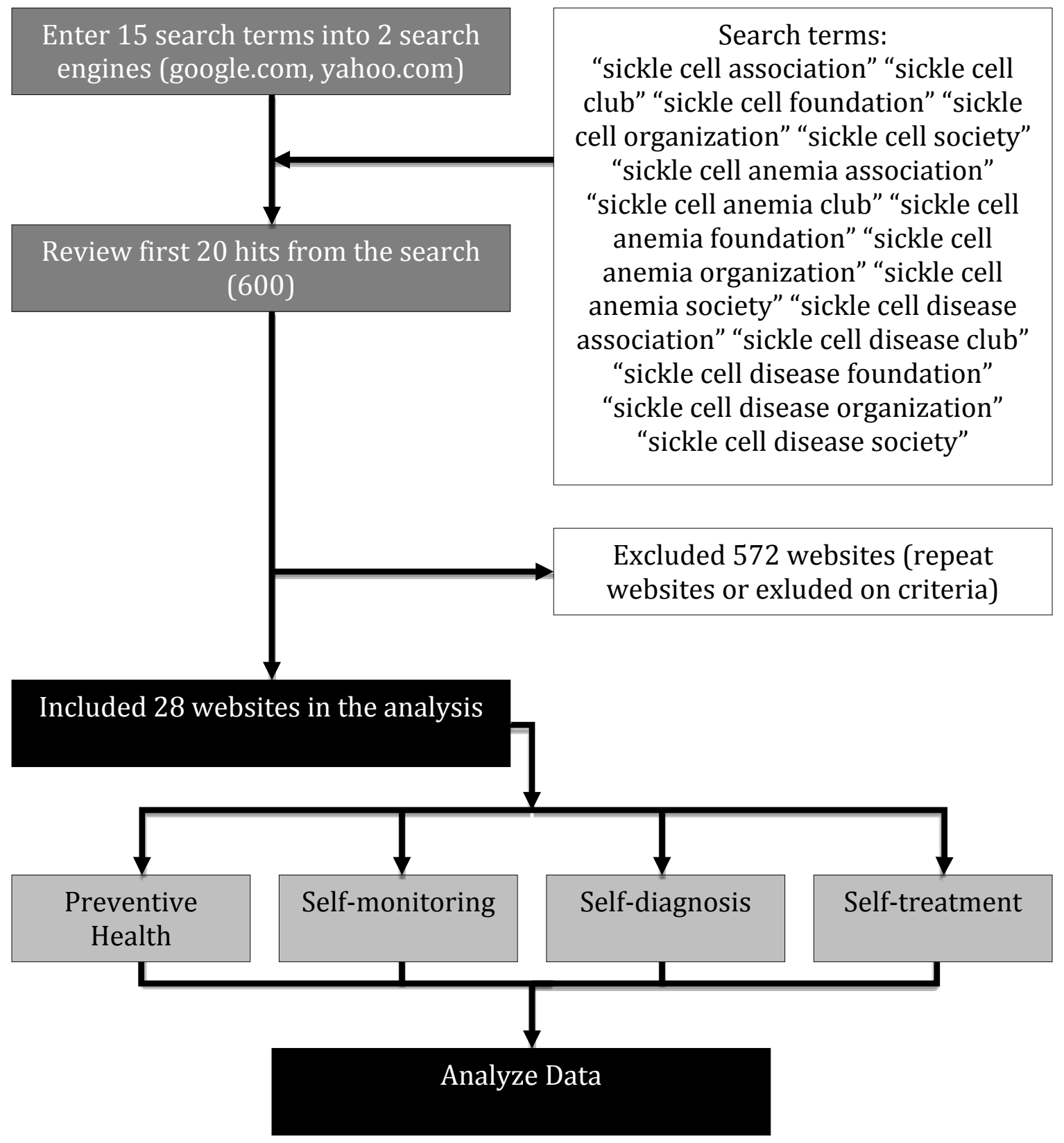




\section{TABLES}

Table 1 Procedures for data collection and analysis

\begin{tabular}{|c|c|}
\hline Publications & Procedure and Steps \\
\hline \multirow{4}{*}{$\begin{array}{l}\text { † Searching } \\
\text { and sampling } \\
\text { the web-wide- } \\
\text { web }\end{array}$} & Searching and sampling the www \\
\hline & $\begin{array}{l}\text { Research question } \\
\text { Formulating the research question or hypothesis }\end{array}$ \\
\hline & $\begin{array}{l}\text { Sampling } \\
\text { Determine sampling units, sampling methods }\end{array}$ \\
\hline & $\begin{array}{l}\text { Data collection and extraction } \\
\text { Determine the time frame for data collection, the unit of analysis/ and } \\
\text { coding units and whether data is downloaded or analyzed online }\end{array}$ \\
\hline \multirow[t]{5}{*}{ †Data Analysis } & $\begin{array}{l}\text { Initial coding categories } \\
\text { Using existing theory or prior research, the researchers begin by } \\
\text { identifying key concepts or variables as the initial coding categories }\end{array}$ \\
\hline & $\begin{array}{l}\text { Operational definition } \\
\text { The operational definition for each category is determined using existing } \\
\text { theory/framework }\end{array}$ \\
\hline & $\begin{array}{l}\text { Coding } \\
\text { Reading the transcripts and highlights all texts that represent the } \\
\text { categories of the theory Coding all the highlighted text using the pre- } \\
\text { determined codes where necessary. }\end{array}$ \\
\hline & $\begin{array}{l}\text { Subcategories } \\
\text { Identifying subcategories through subsequent analysis of the categories }\end{array}$ \\
\hline & $\begin{array}{l}\text { Reporting } \\
\text { Reporting the rank order comparison of the frequency of codes that } \\
\text { represent each category. } \\
\text { Offering descriptive evidence with exemplary codes. }\end{array}$ \\
\hline
\end{tabular}

$\dagger$ McMillan, S. J. (2000). The microscope and the moving target: The challenge of applying content analysis to the World Wide web. Journalism and Mass Communication Quarterly, 77(1), 80-98. doi:10.1177/107769900007700107

$\$$ Hsieh, H. F., \& Shannon, S. E. (2005). Three approaches to qualitative content analysis. Qualitative Health Research, 15(9), 1277-1288. doi:10.1177/1049732305276687 
Table 2 Sources of websites and date accessed

\begin{tabular}{|c|c|c|c|c|}
\hline & Website/ Country & URL & ID & $\begin{array}{l}\text { DATE } \\
\text { ACCESSED }\end{array}$ \\
\hline 1. & $\begin{array}{l}\text { Thalassaemia and Sickle Cell: } \\
\text { Australia (AUSTRALIA) }\end{array}$ & $\underline{\text { http://tascsa.net.au/ }}$ & $\mathrm{AU}$ & $3 / 10 / 2019$ \\
\hline 2. & $\begin{array}{l}\text { Sickle Cell Awareness Group } \\
\text { of Ontario (CANADA) }\end{array}$ & $\underline{\text { http://sicklecellanemia.ca/ }}$ & CA1 & $21 / 3 / 2018$ \\
\hline 3. & $\begin{array}{l}\text { Sickle Cell Association of } \\
\text { Canada (CANADA) }\end{array}$ & $\begin{array}{l}\text { http://www.sicklecelldisease } \\
\text { ca/ }\end{array}$ & CA2 & $8 / 7 / 2019$ \\
\hline 4. & $\begin{array}{l}\text { Sickle Cell Association of } \\
\text { Ontario (CANADA) }\end{array}$ & $\begin{array}{l}\text { https://sites.google.com/a/si } \\
\text { cklecellontario.org/www/ }\end{array}$ & CA3 & $9 / 7 / 2018$ \\
\hline 5. & $\begin{array}{l}\text { Sickle Cell Support Foundation } \\
\text { of Jamaica (JAMAICA) }\end{array}$ & $\begin{array}{l}\text { http://www.sicklecellfounda } \\
\text { tionja.org/ }\end{array}$ & JA & $15 / 6 / 20218$ \\
\hline 6. & $\begin{array}{l}\text { Norwegian Sickle Cell } \\
\text { Association (NORWAY) }\end{array}$ & http://nscao.org/english/ & NW & $5 / 7 / 2018$ \\
\hline 7. & $\begin{array}{l}\text { Sickle Cell Association of } \\
\text { Uganda (UGANDA) }\end{array}$ & $\begin{array}{l}\text { http://www.sicklecelluganda } \\
\text {.org/ }\end{array}$ & UG & $31 / 5 / 2018$ \\
\hline 8. & Sickle Cell Society (UK) & $\begin{array}{l}\text { http://www.sicklecellsociety } \\
\text { org/ }\end{array}$ & UK1 & $5 / 5 / 2018$ \\
\hline 9. & $\begin{array}{l}\text { Organization for sickle cell } \\
\text { anemia relief and thalassemia } \\
\text { support (UK) }\end{array}$ & $\begin{array}{l}\text { http://www.oscarbirmingha } \\
\text { m.org.uk/ }\end{array}$ & UK2 & $3 / 10 / 2019$ \\
\hline 10. & $\begin{array}{l}\text { South Yorkshire Sickle Cell } \\
\text { Organisation (UK) }\end{array}$ & https://www.scyss.org/ & UK3 & $7 / 8 / 2018$ \\
\hline 11. & $\begin{array}{l}\text { Sickle Cell Foundation of } \\
\text { California (USA) }\end{array}$ & http://www.scdfc.org/ & US1 & $3 / 10 / 2019$ \\
\hline 12. & $\begin{array}{l}\text { Sickle Cell Foundation of } \\
\text { Georgia (USA) }\end{array}$ & http://sicklecellga.org/ & US2 & $30 / 9 / 2018$ \\
\hline 13. & $\begin{array}{l}\text { Sickle Cell Information Centre } \\
\text { (USA) }\end{array}$ & http://scinfo.org/ & US3 & $15 / 9 / 2018$ \\
\hline 14. & Net of Care (USA) & $\begin{array}{l}\text { http://www.netofcare.org/co } \\
\text { ntent/specific illnesses/sickl } \\
\text { e cell.asp\#treatmen }\end{array}$ & US4 & $14 / 8 / 2019$ \\
\hline 15. & $\begin{array}{l}\text { Children's Sickle Cell } \\
\text { Foundation Inc (USA) }\end{array}$ & http://cscfkids.org/ & US5 & $8 / 7 / 2018$ \\
\hline 16. & $\begin{array}{l}\text { Sickle Cell Association St- } \\
\text { Louis (USA) }\end{array}$ & $\underline{\mathrm{http}: / / \text { sicklecellassociation.o }}$ & US6 & $1 / 2 / 2018$ \\
\hline 17. & $\begin{array}{l}\text { St Lucia Sickle Cell } \\
\text { Association (USA) }\end{array}$ & $\begin{array}{l}\text { https://stluciasicklecell.wee } \\
\text { bly.com/ }\end{array}$ & US7 & $4 / 5 / 2018$ \\
\hline 18. & $\begin{array}{l}\text { Sickle Cell Association of } \\
\text { Illinois (USA) }\end{array}$ & $\begin{array}{l}\text { https://www.sicklecelldiseas } \\
\text { e-illinois.org/ }\end{array}$ & US8 & $4 / 4 / 2018$ \\
\hline 19. & $\begin{array}{l}\text { Sickle Cell Association of } \\
\text { Florida (USA) }\end{array}$ & http://scdaflorida.com/ & US9 & $4 / 4 / 2018$ \\
\hline 20. & $\begin{array}{l}\text { Sickle Cell Foundation of } \\
\text { Minnesota (USA) }\end{array}$ & $\begin{array}{l}\text { https://www.sicklecellmn.or } \\
\mathrm{g} /\end{array}$ & US10 & $14 / 7 / 2018$ \\
\hline
\end{tabular}




\begin{tabular}{|r|l|l|l|l|}
\hline 21. & $\begin{array}{l}\text { Sickle Cell Association of } \\
\text { National Capital Area Inc } \\
\text { (USA) }\end{array}$ & $\underline{\text { http://scancainc.org/ }}$ & US11 & $14 / 8 / 2018$ \\
\hline 22. & $\begin{array}{l}\text { Sickle Cell Association of BC } \\
\text { (USA) }\end{array}$ & $\begin{array}{l}\text { http://www.sicklecellassocia } \\
\text { tionofbc.com/ }\end{array}$ & US12 & $11 / 7 / 2018$ \\
\hline 23. & $\begin{array}{l}\text { Sickle Cell Association } \\
\text { Hillsborough County (USA) }\end{array}$ & $\begin{array}{l}\text { http://www.scahillsborough. } \\
\text { org/ }\end{array}$ & US13 & $6 / 10 / 2018$ \\
\hline 24. & $\begin{array}{l}\text { The Sickle Cell Disease } \\
\text { Coalition (USA) }\end{array}$ & $\underline{\text { http://www.scdcoalition.org/ }}$ & US14 & $17 / 3 / 2018$ \\
\hline $25 \cdot$ & $\begin{array}{l}\text { Sickle Cell Disease (for } \\
\text { Parents) - KidsHealth (USA) }\end{array}$ & $\begin{array}{l}\text { https://kidshealth.org/en/par } \\
\text { ents/sickle-cell-anemia.html }\end{array}$ & US15 & $4 / 10 / 2019$ \\
\hline 26. & $\begin{array}{l}\text { Sickle Cell Cure Foundation } \\
\text { (USA) }\end{array}$ & $\begin{array}{l}\text { http://sicklecellcurefoundati } \\
\text { on.org/ }\end{array}$ & US16 & $3 / 10 / 2019$ \\
\hline 27. & $\begin{array}{l}\text { Peninsula Association of Sickle } \\
\text { Cell Anemia (USA) }\end{array}$ & $\begin{array}{l}\text { http://www.orgsites.com/va/ } \\
\text { pasca }\end{array}$ & US17 & $3 / 10 / 2019$ \\
\hline 28. & $\begin{array}{l}\text { Sickle Cell Disease Association } \\
\text { of America (USA) }\end{array}$ & $\begin{array}{l}\text { https://www.sicklecelldiseas } \\
\text { e.org/ }\end{array}$ & US18 & $4 / 4 / 2018$ \\
\hline
\end{tabular}


Table 3: Sources of health education materials analyzed

\begin{tabular}{|l|r|r|r|r|}
\hline Webpage & Audio-visuals & Books & \multicolumn{1}{l|}{$\begin{array}{l}\text { Leaflets/ } \\
\text { posters }\end{array}$} & PowerPoint \\
\hline AU & CA3 (6) & UK1 (1) & UK1(3) & UK3 (1) \\
CA1, CA2, CA3 & JA (4) & US3 (5) & US1 (2) \\
JA & & US14 (1) & US3 (1) \\
NW & & & US14 (1) \\
UG & & & US18 (7) \\
UK1, UK2 & & & \\
US2, US3, US4, & & & \\
US5, US6, US7, & & & \\
US8, US10, & & & \\
US11, US12, & & & \\
US13, US15, & & & \\
US16, US 18 & & & \\
\hline $23(40.4 \%)$ & $10(17.5 \%)$ & & \\
\hline Total $=57$ & & & \\
\hline
\end{tabular}


Table 4A: Summary of preventive health, self- monitoring and self-diagnosis recommendations

\begin{tabular}{|c|c|}
\hline Self-management category & Specific self-management actions \\
\hline $\begin{array}{l}\text { Preventive Health } \\
\text { Websites }(\mathbf{n = 2 2}) \\
\text { AU } \\
\text { CA1, CA2, CA3 } \\
\text { JA } \\
\text { NW } \\
\text { UG } \\
\text { UK1 } \\
\text { US1, US2, US3, US4, US5, US6, } \\
\text { US8, US9, US10, US11, US12, } \\
\text { US13, US16, US17 }\end{array}$ & $\begin{array}{l}\text { - Taking regular oral fluids (Hydration) } \\
\text { - } \text { Eating a healthy diet } \\
\text { - Taking supportive medication } \\
\text { - Maintaining personal hygiene \& infection prevention } \\
\text { - Avoiding over-activity \& low oxygen environments } \\
\text { - Avoiding extremes of temperature } \\
\text { - Avoiding medicines, food, \& beverages that can trigger } \\
\text { - } \text { the crisis }\end{array}$ \\
\hline $\begin{array}{l}\text { Self-Monitoring } \\
\text { Websites }(\mathbf{n}=\mathbf{1 0}) \\
\text { CA3 } \\
\text { UG } \\
\text { UK1, UK3 } \\
\text { US1, US3, US4, US8, US12, US14 }\end{array}$ & $\begin{array}{ll}\text { - } & \text { Pain monitoring } \\
\text { - } & \text { Temperature monitoring } \\
\text { - } & \text { Daily inspection for pallor, jaundice \& skin conditions } \\
\text { - } & \text { Splenic palpation } \\
\text { - } & \text { Monitoring for stroke among children } \\
\text { - } & \text { Growth monitoring among children } \\
\end{array}$ \\
\hline $\begin{array}{l}\text { Self-Diagnosis } \\
\text { Websites }(\mathbf{n}=\mathbf{1 1}) \\
\text { CA1, CA3 } \\
\text { UG } \\
\text { UK1, UK3 } \\
\text { US3, US6, US10, US11, US12, } \\
\text { US13 }\end{array}$ & $\begin{array}{l}\text { - } \text { Presence of fever and other infections } \\
\text { - } \text { Observing local and systemic signs of anemia } \\
\text { - } \text { Detecting leg ulcers or wounds } \\
\text { - } \quad \text { Experience of persistent or worsening pain } \\
\text { - } \text { Breathing difficulty } \\
\text { - } \quad \text { Experiencing priapism episodes } \\
\text { - } \text { Observing or palpating an enlarged spleen } \\
\text { - } \text { Observing signs of stroke } \\
\text { - } \quad \text { Sudden vision loss }\end{array}$ \\
\hline
\end{tabular}


Table 4B Summary of self-treatment recommendations

\begin{tabular}{|c|c|}
\hline Condition & Specific self-management actions \\
\hline $\begin{array}{l}\text { Pain } \\
\text { Websites }(\mathbf{n}=\mathbf{1 2}) \\
\text { CA1, CA3 } \\
\text { UG } \\
\text { UK1 } \\
\text { US1, US2, US3, US4, US6, US11, } \\
\text { US12, US18 }\end{array}$ & $\begin{array}{l}\text { - Using analgesics } \\
\text { - Taking extra fluids } \\
\text { - Applying heat } \\
\text { - Massaging painful areas } \\
\text { - Resting the body } \\
\text { - Engaging in quiet play } \\
\text { - Using distraction } \\
\text { - Having a personal pain preparedness plan }\end{array}$ \\
\hline $\begin{array}{l}\text { Leg ulcer } \\
\text { Websites }(\mathbf{n}=\mathbf{5}) \\
\text { CA3 } \\
\text { UG } \\
\text { US1, US3, US6 }\end{array}$ & $\begin{array}{l}\text { - Wearing compression garments } \\
\text { - Bed rest with leg elevations } \\
\text { - Wearing cotton stocks and flat protective shoes } \\
\text { - Using lotions or ointments to keep the skin moist } \\
\text { - Using fresh bandage on ulcer every day } \\
\text { - Covering or bandaging scars }\end{array}$ \\
\hline $\begin{array}{l}\text { Fever } \\
\text { Websites }(\mathbf{n}=4) \\
\text { CA1 } \\
\text { NW } \\
\text { US3, US6 }\end{array}$ & $\begin{array}{l}\text { - Taking antipyretics with a consultation with health } \\
\text { professionals } \\
\text { - Avoiding the use of salicylates } \\
\text { - Taking or giving child extra fluids }\end{array}$ \\
\hline $\begin{array}{l}\text { Priapism } \\
\text { Websites }(\mathbf{n}=4) \\
\text { UG } \\
\text { UK1, UK2 } \\
\text { US11 }\end{array}$ & $\begin{array}{l}\text { - } \quad \text { Drinking extra fluids } \\
\text { - } \text { Emptying the bladder frequently } \\
\text { - Practicing relaxation skills }\end{array}$ \\
\hline $\begin{array}{l}\text { Bedwetting } \\
\text { Websites }(\mathbf{n}=\mathbf{3}) \\
\text { UK1 } \\
\text { US3, US11 }\end{array}$ & $\begin{array}{l}\text { - } \text { Reducing fluid intake at nigh } \\
\text { - } \text { Bladder training } \\
\text { - } \text { Awarding the child for success }\end{array}$ \\
\hline $\begin{array}{l}\text { Dactylitis } \\
\text { Websites }(\mathbf{n}=\mathbf{3}) \\
\text { CA1 } \\
\text { US6, US18 }\end{array}$ & $\begin{array}{l}\text { - } \text { Placing the affected hand in a bandage } \\
\text { - Giving more fluids to the affected child } \\
\text { - Giving analgesics to child } \\
\text { - Avoiding pressing or rubbing the affected part }\end{array}$ \\
\hline $\begin{array}{l}\text { Avascular necrosis of head of } \\
\text { femur } \\
\text { Websites }(n=2) \\
\text { US1, US3 }\end{array}$ & $\begin{array}{l}\text { - } \quad \text { Engaging in low impact activities } \\
\text { - Avoiding lifting heavy objects } \\
\text { - Avoiding jumping and jogging } \\
\text { - Taking calcium and vitamin D supplements }\end{array}$ \\
\hline
\end{tabular}

